NBER WORKING PAPER SERIES

\title{
GLOBALIZATION AND COMPLEMENTARY POLICIES: POVERTY IMPACTS IN RURAL ZAMBIA
}

\author{
Jorge F. Balat \\ Guido G. Porto \\ Working Paper 11175 \\ http://www.nber.org/papers/w11175 \\ NATIONAL BUREAU OF ECONOMIC RESEARCH \\ 1050 Massachusetts Avenue \\ Cambridge, MA 02138 \\ March 2005
}

\begin{abstract}
We are indebted to A. Harrison for her support. The discussion among participants at the NBER conference on Globalization and Poverty was very useful. We wish to specially thank our discussant, M. Slaughter, for his very useful comments and suggestions. Conversation with W. Easterly helped us clarify our understanding of some important issues; we thank him for his insights. Support from F. Yagci and R. Kirk at the Zambia DTIS is greatly appreciated. All errors are our responsibility. This paper is part of the NBER's research program in Public Economics. Any opinions expressed are those of the authors and not those of ESRI or the National Bureau of Economic Research.

(C) 2005 by Jorge F. Balat and Guido Porto. All rights reserved. Short sections of text, not to exceed two paragraphs, may be quoted without explicit permission provided that full credit, including $\odot$ notice, is given to the source.
\end{abstract}


Globalization and Complementary Policies: Poverty Impacts in Rural Zambia

Jorge F. Balat and Guido Porto

NBER Working Paper No. 11175

March 2005

JEL No. I32, Q12, Q17, Q18

\section{ABSTRACT}

In this paper, we have two main objectives: to investigate the links between globalization and poverty observed in Zambia during the 1990s, and to explore the poverty impacts of non-traditional export growth. We look at consumption and income effects separately. On the consumption side, we study the maize marketing reforms and the elimination of maize subsidies. We find that complementary policies matter: the introduction of competition policies at the milling industry acted as a cushion that benefited consumers but the restriction on maize imports by small-scale mills hurt them. On the income side, we study agricultural export growth to estimate income gains from international trade. The gains are associated with market agriculture activities (such as growing cotton, tobacco, hybrid maize) and rural labor markets and wages. We find that by expanding trade opportunities Zambian households would earn significantly higher income. Securing these higher levels of well-being requires complementary policies, like the provision of infrastructure, credit, and extension services.

Jorge F. Balat

Mail Stop MC3-303

World Bank

1818 H Street

Washington, DC 20433

jbalat@worldbank.org

Guido Porto

Mail Stop MC3-303

World Bank

1818 H Street

Washington, DC 20433

gporto@worldbank.org 


\section{Introduction}

During the last decade, Zambia adopted several economic reforms, including macroeconomic stabilization measures, trade liberalization, export promotion, and the elimination of marketing boards in maize and cotton. These reforms were expected to be beneficial in terms of national welfare, diversity in consumption, and productivity growth. The effects on the distribution of income and poverty were more uncertain, and positive impacts at the household level were harder to secure. In fact, poverty in Zambia increased during the 1990s. In this paper, we have two main objectives: to investigate the links between trade, complementary policies and poverty observed in Zambia during the last decade, and to explore how new trade alternatives may bring about poverty alleviation in the future.

International trade introduces new opportunities and new hazards. Households are affected both as consumers and as producers or income earners. As consumers, households are affected when there are changes in the prices of goods consumed by the family. As income earners, households are affected when there are responses in wages and in agricultural income. In this paper, we examine the two sides of the globalization-poverty link. Since rural poverty is widespread in Zambia, we focus our analysis on rural households.

We carry out a series of separate poverty exercises related to the consumption and income impacts. On the income side, we are interested in exploring some of the dynamics effects of international trade on rural areas and agricultural activities. By facilitating access to larger international markets and by boosting non-traditional export sectors, trade provides incentives for rural households to move from subsistence to market-oriented agriculture. To capture these effects, we identify relevant agricultural activities, by providing a detailed description of household productive activities, and we estimate the income differential generated by market agriculture over subsistence agriculture using matching methods. These estimates provide a quantification of the income gains that may arise due to access to international markets and to the expansion of non-traditional exports.

On the consumption side, we look at the effects of the removal of maize subsidies. There are two critical observations that support our somewhat narrow focus. On the one hand, Zambian households devote a very large fraction of total expenditure to food and, within food 
items, to maize; on the other, one of the major agricultural reforms comprised the elimination of the maize marketing board. In addition, we can use this experiment to look at the role of complementary policies. Concretely, the increase in the price of maize was expected to cause large welfare effects. But it triggered substitution effects towards cheaper varieties of maize that was only possible when the government facilitated entry into the small-scale mill industry. This is an instance in which complementary policies allowed households to smooth some of the welfare impacts of the increase in maize prices. However, the government restricted maize imports by small mills, or gave preference over publicly imported maize to industrial mills, and this hurt consumers in times of production shortages.

The paper is organized as follows. In Section 2, we describe the trends in poverty observed in Zambia during the 1990s, we review the major reforms adopted during this period, and we characterize trends in traditional (mining) and non-traditional (agriculture) exports. In Section 3, we look at sources of income and we estimate income differential gains in market agriculture. In section 4, we study the expenditure patterns of Zambian households and we explore the welfare costs of the elimination of consumption subsidies on maize. Section 5 concludes.

\section{Trade and Poverty in Zambia}

Zambia is a landlocked country located in southern central Africa. Clockwise, neighbors are Congo, Tanzania, Malawi, Mozambique, Zimbabwe, Botswana, Namibia, and Angola. In 2000, the total population was 10.7 million inhabitants. With a per capita GDP of only 302 US dollars, Zambia is one of the poorest countries in the world and is considered a least developed country. The goal of this section is to provide a brief characterization of trade and poverty in Zambia.

\subsection{Poverty}

Zambia faces two poverty ordeals: it is one of the poorest countries in the world, and it suffered from increasing poverty rates during the 1990s. The analysis of the trends in poverty 
rates can be done using several household surveys. There are four of them in Zambia, two Priority Surveys, collected in 1991 and 1993, and two Living Conditions Monitoring Surveys, in 1996 and 1998. All the surveys have been conducted by the Central Statistical Office (CSO) using the sampling frame from the 1990 Census of Population and Housing.

The Priority Survey of 1991 is a Social Dimension of Adjustment (SDA) survey. It was conducted between October and November. The survey is representative at the national level and covers all provinces, rural and urban areas. A total of 9,886 households was interviewed. Questions on household income, agricultural production, non-farm activities, economic activities, and expenditures were asked. Own-consumption values were imputed after the raw data were collected. Other questions referred to household assets, household characteristics (demographics), health, education, economic activities, housing amenities, access to facilities (schools, hospitals, markets), migration, remittances and anthropometry. ${ }^{1}$

The 1996 and 1998 Living Conditions Monitoring Surveys expanded the sample to around 11,750 and 16,800 households respectively. The surveys included all the questions covered in the Priority Survey of 1991, expanded the questionnaires to issues of home consumption and coping strategies, and gathered more comprehensive data on consumption and income sources.

Table 1 provides some information on poverty dynamics. In 1991, the poverty rate at the national level was 69.6 percent. Poverty increased in 1996, when the head count reached 80 percent, and then declined towards 1998, with a head count of 71.5 percent. In rural areas, poverty is widespread; the head count was 88.3 percent in 1991, 90.5 percent in 1996 and 82.1 percent in 1998. Urban areas fared better, with a poverty rate of 47.2 percent in 1991 , 62.1 percent in 1996 and 53.4 percent in 1998.

In Table 2, a more comprehensive description of the poverty profile, by provinces, is provided for 1998. Zambia is a geographically large country, and provinces differ in the quality of land, weather, access to water, and access to infrastructure. The capital Lusaka and the Copperbelt area absorbed most of the economic activity particularly when mining and copper powered the growth of the economy. The Central and Eastern provinces are

\footnotetext{
${ }^{1}$ The 1993 Priority Survey was conducted during a different agricultural season and is therefore not comparable.
} 
cotton production areas. The Southern Province houses the Victoria Falls and benefits from tourism. The remaining provinces are less developed.

There were significant differences in the poverty rates across regions. All provinces showed aggregate poverty counts higher than 60 percent, except for Lusaka, the capital (48.4 percent). Poverty in Copperbelt was 63.2 percent and in Southern, 68.2 percent. The highest head count was observed in the Western province, where 88.1 percent of the total population lived in poverty. The other provinces showed head counts in the range of 70 to 80 percent. Poverty was much higher in rural areas than in urban areas. Even in Lusaka, a mostly urban location, rural poverty reached over 75 percent. In the Western province, 90.3 percent of the rural population lived in poverty in 1998. Urban poverty was lower, never exceeding 70 percent of the population (including the Western province).

\subsection{Major Reforms}

The Republic of Zambia achieved Independence in 1964. A key characteristic of the country is its abundance in natural resources, particularly mineral deposits (like copper) and land. Due to high copper prices, the new Republic did quite well in the initial stages of development. Poverty and inequality, however, were widespread and this raised concerns among the people and the policymakers. Soon, the government began to adopt interventionist policies, with a much larger participation of the state in national development. Interventions included import substitution, price controls of all major agricultural products (like maize), nationalization of manufacturing, agricultural marketing and mining.

In the 1970s and 1980s, the decline in copper prices and the negative external conditions led to stagnation and high levels of external debt. A crisis emerged and a structural adjustment program was implemented between 1983 and 1985. Riots in 1986 forced the government to later abandon the reforms in 1987. A second IMF programme failed in 1989, when the removal of controls in maize led to significant price increases.

In 1991, the Movement for Multi-Party Democracy (MMD) was elected. Faced with a sustained, severe recession and with a meager future, the new government began economy-wide reforms including macroeconomic stabilization, exchange rate liberalization, 
fiscal restructuring, removal of maize subsidies, decontrol of agricultural prices, privatization of agricultural marketing, and trade and industrial policy. Table 3, reproduced from McCulloch et al. (2001), describes the major reforms adopted during the 1990s.

A major component of the reforms of the 1990s was the elimination of the marketing boards in maize and cotton. Before 1994, intervention in cotton markets was widespread and involved setting prices for sales of certified cotton seeds, pesticides, and sprayers, providing subsidized inputs to producers, facilitating access to credit, etc. ${ }^{2}$ From 1977 to 1994, the Lint Company of Zambia (Lintco) acted as a nexus between local Zambian producers and international markets. Lintco had a monopsony in seed cotton markets, and a monopoly in inputs sales and credit loans to farmers.

These interventions were eliminated in 1994, when markets were liberalized. Early after liberalization, Lintco was sold to Lonrho Cotton and a domestic monopsony was formed. Subsequent entry led to geographical monopsonies rather than national oligopsonies since firms segmented the market geographically. By 1997, the expansion of the cotton production base attracted new entrants. Instead of the localized monopsonies, competition ensued.

At present, most cotton production in Zambia is carried out under outgrower schemes. There are two systems utilized by different firms: the Farmer Group System and the Farmer Distributor System. In the latter, firms designate one individual or farmer as the distributor and provide inputs. The distributor prepares individual contracts with the farmers. He is also in charge of assessing reasons for loan defaults, being able, in principle, of condoning default in special cases. He is in charge of renegotiating contracts in incoming seasons. In the Farmer Group System, small scale producers deal with the ginneries directly, purchasing inputs on loan and repaying at the time of harvest. Both systems seem to work well.

Fueled by high copper prices and exports, Zambia maintained, during the 1970s and 1980s, large systems of maize production and consumption subsidies. They were administered by marketing boards. External shocks (the collapse of copper prices) and inappropriate domestic policies made marketing boards unsustainable and led to their elimination in the reforms of the 1990s. The removal of the distortions was supposed to

\footnotetext{
${ }^{2}$ For more details on cotton reforms in Zambia, see Food Security Research Project (2000) and Cotton News (2002).
} 
bring about aggregate welfare gains. In practice, the effects on household welfare critically depended on complementary policies like the provision of infrastructure and the introduction of competition policies. ${ }^{3}$

In 1993, the government began reforming the maize pricing and marketing system, eliminating subsidies, and removing international trade restrictions. The most important reforms consisted of the removal of all price controls (including pan-territorial and pan-seasonal pricing), and the decentralization of maize marketing and processing. At present, the marketing board has been fully eliminated. However, as of 2001, the government implemented a floor price for production of maize.

\subsection{Trade Trends}

Zambia's major trading partners are the Common Market for Eastern and Southern Africa (COMESA), particularly Zimbabwe, Malawi and Congo, South Africa, the EU and Japan. The main imports comprise petroleum, which account for 13.2 percent of total imports in 1999, metals (iron, steel), for 16.9 percent, and fertilizers, for 13 percent. Other important import lines include chemicals, machinery, and manufactures.

Zambian exports have been dominated by copper. In fact, since Independence and up to 1990, exports consisted almost entirely of copper, which accounted for more that 90 percent of total export earnings. Only recently has diversification into non-traditional exports become important. The details are in Table 4, which reports the evolution and composition of exports from 1990 to 1999. In 1990, metal exports accounted for 93 percent of total commodity exports. Non-traditional exports, such as primary products, agro-processing, and textiles, accounted for the remaining 7 percent. From 1990 to 1999, the decline in metal exports and the increase in non-traditional exports are evident. In 1999, for example, 61 percent of total exports comprised metal products, while 39 percent were non-traditional exports. Within non-traditional exports, the main components are primary products, floricultural products, textiles, processed foods, horticulture, textiles, and animal products.

The last column of Table 4 reports some informal export growth projections for some of

\footnotetext{
${ }^{3}$ For a description of the early reforms in maize marketing and pricing, see World Bank (1994).
} 
the non-traditional categories. Notice that agriculture is expected to grow at a high rate

over the decade, contributing to nearly 20 percent of total exports, up from less than 2 percent in 1990. For COMESA and SADC (Southern Africa Development Community), cotton, tobacco, meat, poultry, dairy products, soya beans, sunflower, sorghum, groundnuts, paprika, maize, and cassava are promising markets. For markets in developed countries (the EU, the US), coffee, paprika, sugar, cotton, tobacco, floriculture, horticulture, vegetables, groundnuts, and honey comprise the best prospects for export growth.

Exports are largely liberalized. There are no official export taxes, charges or levies. Further, export controls and regulations are minimal. Maize exports, however, are sometimes subject to bans for national food security reasons. In 2002, for instance, the export ban on maize was in place. There are some export incentives, from tax exemptions to concessions to duty drawback. For example, an income tax of 15 percent (instead of the standard 35 percent rate) is granted to exporters of non-traditional goods who hold an investment license. Also, investments in tourism are sometimes exempted from duties.

\section{Income}

We are most interested in exploring the effects of trade on the income of Zambian households. By affecting wages and cash agricultural income, trade opportunities are likely to have large impacts on household resources and on poverty. As argued by Deaton (1997) and others, the short-run effects of price changes can be assessed by looking at income shares. In Table 5, we report the average income shares for different sources of income. At the national level, the main sources of income are income from home consumption (28.3 percent), income from non-farm businesses (22.3 percent) and wages (20.8 percent). Regarding agricultural income, the sale of Food crops accounts for 6.3 percent of total income, while the sale of Cash crops, for only 2.5 percent. Livestock \& Poultry and Remittances account for 5.5 and 4.9 percent of household income, respectively.

There are important differences in income sources between poor and non-poor households. While the share of own-production is 33.3 percent in the average poor household, it is 19.1 
percent in non-poor families. In contrast, while wages account for 32.9 percent of the total income of the non-poor, they account for only 14.1 percent of the income of the poor. The shares of the income generated in non-farm businesses are 20.8 and 25 percent in poor and non-poor households respectively. The poor earn a larger share of income from the sales of both food and cash crop, and lower shares from livestock and poultry.

It is interesting to compare the different sources of income across rural and urban areas. In rural areas, for instance, 42.5 percent of total income is accounted for by own-production; the share in urban areas is only 3.3 percent. The share of non-farm income in rural areas is 16.7 percent, which should be compared with a 32.1 percent in urban areas. In rural areas, the shares from food crops, livestock, wages and cash crops are 9.1, 8.1, 6.9 and 3.8 respectively. In urban areas, in contrast, wages account for 45.3 percent of household income, and the contribution of agricultural activities is much smaller.

The description of income shares is also useful because it highlights the main channels through which trade opportunities can have an impact on household income. We can conclude that, in rural areas, households derive most of their income from subsistence agricultural and non-tradable services (non farm income). Cash crop activities and agricultural wages comprise a smaller fraction of total household income. In our analysis of the differential impacts of trade on household income, we focus on these last farm activities for they are more likely to be directly affected by international markets. ${ }^{4}$

We explore the poverty alleviation effects of growth in non-traditional exports. If trade leads to higher prices for agricultural goods or higher wages, then there is a first order impact on income given by the income shares described in Table 5. But changes in the extensive margin should be expected, too. In rural areas, this involves farmers switching from subsistence to market-oriented agriculture. For instance, small-scale producers of own-food are expected to benefit from access to markets by producing higher-return cash crops, such as cotton, tobacco, groundnuts or non-traditional exports such as vegetables.

It is this attempt to identify and estimate second round effects of increased market opportunities in rural areas that distinguishes this paper from most of the current literature.

\footnotetext{
${ }^{4}$ Notice that there may be spillover effects if trade causes growth in income and this leads to higher expenditures on non-tradable good and services. We are unable to capture these effects in the data.
} 
Starting with the pioneering work of Deaton (1989) and (1997), estimation of first order effects in consumption and income has become widespread. Techniques to estimate substitution in consumption are also available (Deaton, 1990). But estimation of supply responses has proved much more difficult. The survey in Winters, McCulloch and McKay (2004) highlights these issues and reports some of the available methods and results. In this paper, we capture supply responses using matching methods: by matching households in subsistence agriculture with household in market agriculture, we are able to estimate the average income differential generated by market oriented activities. We do this for different crops as follows.

In rural areas, there are two main channels through which new trade opportunities can affect household income. ${ }^{5}$ On the one hand, households produce agricultural goods that are sold to agro-processing firms. This involves what we call cash crop activities. On the other hand, household members may earn a wage in a large scale agricultural farm. This means that workers, instead of working in home plots for home production or cash crops, earn a wage in rural (local) labor markets. In this paper, we focus on these two types of activities.

We begin by identifying meaningful agricultural activities for the poverty analysis. Due to regional variation in soil, climate, and infrastructure, the relevant sources of income may be different for households residing in different provinces. To see this, we report in Table 6 the main sources of household income in the rural areas of the nine Zambian provinces. For each agricultural activity, the table shows the average share of total income accounted for by a given activity, the mean household income conditional on having positive income in a given activity, and the sample size, the number of households that are active in that particular agricultural activity.

Looking at income shares first, we observe that in the Central, Eastern and Southern provinces, the most relevant cash crop activity is cotton. Poultry and Livestock are also important sources of income, particularly in the Southern Province. Tobacco is a promising activity in the Eastern Province, and hybrid maize in the Central province. In the Copperbelt, the most relevant activities are vegetables and hybrid maize; in Luapula, they

\footnotetext{
${ }^{5}$ See Porto (2004) for a descriptive household production model with these features. This model builds on previous work by Singh, Squire and Strauss (1986), Barnum and Squire (1979) and Benjamin (1992).
} 
are groundnuts and cassava; in Northern, cassava and beans; and in North-Western, cassava. In all the provinces, Livestock and Poultry are two good sources of agricultural income.

A key aspect of international trade is that it opens up markets for new products. This implies that some relatively minor sources of income may become quantitatively more important as non-traditional exports grow. Notice, however, that in order to extract meaningful information from the LCMS household survey, we face the practical constraint of sample sizes in our analysis. The data on the number of households reporting positive income and the average value of income for different agricultural activities reported in Table 6 give a sense of the potential relevance of those activities. Based on this information, we identify the following meaningful agricultural activities: cotton, vegetables (including beans), tobacco (in the eastern province only), groundnuts, hybrid maize, cassava, sunflower, and livestock and poultry.

We turn now to a description of the methods that we use. Our aim is to estimate the differential income generated by market agricultural activities vis-a-vis subsistence agriculture, and to explore the poverty alleviation effects of allowing for an expansion of cash market activities among Zambian farmers. We use matching methods based on the propensity score. There is a large literature on matching methods. Original pieces include Rubin (1977) and Rosembaun and Rubin (1983). More recently, Heckman, Ichimura and Todd (1997) and (1998), and Heckman, Ichimura, Smith and Todd (1996) extended and assessed these methods. Dehejia and Wahba (2002) provided a practical examination of propensity score matching methods using the data in Lalonde (1986).

We perform separate matching exercises, one for each of the cash agricultural activities previously identified in Table 6 (i.e. cotton, tobacco, hybrid maize, groundnuts, vegetables, cassava, sunflower, and rural labor markets). ${ }^{6}$ We estimate a probit model of participation into market agricultural, which defines the propensity score $p(\mathbf{x})$, for a given vector of observables $\mathbf{x}$. Subsistence farmers are matched with market farmers based on this propensity score, and the income differential is estimated using kernel methods. Details follow.

\footnotetext{
${ }^{6}$ We do not consider the case of Livestock and Poultry because, first, it seems reasonable to assume that this activity requires larger initial investments and, second, because Zambia has not dealt with the problem of animal disease yet.
} 
Let $y_{h}^{m}$ be the income per hectare in market agriculture (e.g. cotton) of household $h$. Let $y_{h}^{s}$ be the home produced own consumption per hectare. Define an indicator variable $M$, where $M=1$ if the household derives most of their income from cash agriculture. In practice, most Zambian households in rural areas produce something for own consumption. As a consequence, we assign $M=1$ to households that derive more than 50 percent of their income from a given cash agricultural activity. Households that derive most of their income from home production are assigned $M=0$. The propensity score $p(\mathbf{x})$ is defined as the conditional probability of participating in market agriculture

$$
p(\mathbf{x})=P(M=1 \mid \mathbf{x}) .
$$

We are interested in estimating the average income differential of those involved in cash market agriculture. This can be defined as

$$
\tau=E\left[y_{h}^{m}-y_{h}^{s} \mid M=1\right] .
$$

The main assumption of matching methods is that the participation into market agriculture can be based on observables. This is the ignorability of treatment assignment. More formally, we require that $y_{h}^{m}, y_{h}^{s} \perp M \mid \mathbf{x}$. When the propensity score is balanced, we know that $M \perp \mathbf{x}$ $\mid p(\mathbf{x})$. This means that, conditional on $p(\mathbf{x})$, the participation in market agriculture $M$ and the observables $\mathbf{x}$ are independent. In other words, observations with a given propensity score have the same distribution of observables $\mathbf{x}$ for households involved in market agriculture as in subsistence. The importance of the balancing property, which can be tested, is that it implies that

$$
y_{h}^{m}, y_{h}^{s} \perp M \mid p(\mathbf{x}) .
$$

This means that, conditionally on $p(\mathbf{x})$, the returns in market agriculture and in subsistence are independent of market participation, which implies that households in subsistence and in cash agriculture are comparable. 
In general, the assumption that participation depends on observables can be quite strong. In Zambia, the decision to be involved in market agriculture seems to depend on three main variables: access to markets, food security, and tradition in subsistence agriculture. Farmers need market access to sell their agricultural products. In Zambia, many farmers reveal strong preferences to secure food needs before engaging in market agriculture. This behavior is probably affected by issues of risk aversion and lack of insurance. Tradition in agriculture may be the consequence of risk aversion, but may be related to know-how and social capital in food agriculture. We capture these effects by including in the propensity function several key control variables like regional (district) dummies, the size of the household, the demographic structure of the family, the age and the education of the household head, and the availability of agricultural tools. We believe these variables $\mathbf{x}$ comprise a comprehensive set of observables to explain the selection mechanism. ${ }^{7}$ Table 7 reports the results of the estimation of the probit model for the most important cash agriculture crops.

In all our exercises, the balancing condition is tested following the procedure suggested by Dehejia and Whaba (2002). In all the cases, except for paprika and sunflower, the balancing property is satisfied. This is a minor requirement that we impose in our procedure (we cannot test the ignorability requirement). In addition, as suggested by Dehejia and Whaba (2002) and Heckman et al. (1997, 1998), we graph histograms of the propensity score for those in market and those in subsistence. For the case of cotton, for example, such a plot is reported in Figure 1. These graphs are important because they reveal the usefulness of the estimated propensity score as a predictor of the selection process. Since we are matching farmers on the basis of these propensity scores, we would like to find that the predicted probability for those farmers in subsistence is similar to the predicted probabilities for those farmers actually doing cash agriculture. In other words, these graphs shows the number of subsistence farmers that can be meaningfully matched with cotton farmers. In Figure 1, for instance, we find sufficient overlaps in the propensity scores. ${ }^{8}$ This means that, at least in the region of common support of the propensity score, there are enough comparison units to

\footnotetext{
${ }^{7}$ The role of other important variables, such as rainfall or temperature which are not directly available, is captured by the district dummies.

${ }^{8}$ Similar results are found in most of the other agricultural activities considered in this paper.
} 
match each cotton producer. ${ }^{9}$

There are two models that we want to explore, the constrained household model and the unconstrained household model. In the latter, households are assumed not to face significant constraints in terms of land, family labor supply, or inputs. This means that it would be possible for the household to plant an additional hectare of, say, cotton or cassava. In this case, the relevant quantity to estimate is the income that could be earned in cash activities. There would be no forgone income by expanding cash crop activities. In contrast, in the constrained household model, land or labor impose a limitation to farming activities. If a family were to plant an additional acre of cotton, then an acre of land devoted to own-consumption (and other relevant resources) should be released.

It is unclear which model better explains the situation in Zambia. In some regions, land availability seems not to be a real constraint and farmers could in principle use additional hectares at no cost. In some places, labor supply and labor discipline seem to be a more important limitation. Access to seeds and inputs is relatively widespread in the case of cotton due to the outgrower scheme (section 2). Other crops, such as hybrid maize, may require purchases of seeds in advance, something that may be difficult for many farmers. Fertilizers may also be expensive, but governmental subsidy programs in place may help ease the constraints. In any case, it is our belief that important lessons can be learnt from the comparison of the results in the two models. The constrained model would give a sense of the short run benefits of moving away from subsistence to market agriculture. The unconstrained model would reveal the additional benefits to Zambian farmers of helping release major agricultural constraints.

Results are reported in Table 8. The first vertical panel corresponds to the gains per hectare in the constrained model. In the second panel, the constrained household is assumed to expand cash agricultural activities by the average size of the plots devoted to each of these activities. The third panel reports the gains per hectare in the unconstrained model; this model is directly comparable to that in the first panel. The last panel reports the gains in the unconstrained model in the hypothetical situation in which the farmer moves from

\footnotetext{
${ }^{9}$ It is recommended that farmers in the region of non-common support be excluded from the sample. We followed this suggestion in the estimation of the average effects.
} 
subsistence to market, but devoting the average area to the market crop.

We begin by describing the case of cotton, the major market crop in some provinces. In the constrained model, farmers growing cotton are expected to gain 18,232 kwachas, on average, more than similar farmers engaged in subsistence agriculture. The gain is equivalent to 19.9 percent of the average expenditure of a representative poor farmer. To get a better sense of what these numbers mean, notice that the food poverty line in 1998 was estimated at $\mathrm{Kw} 32,233$ per month and the poverty line, at 46,287 per month (per equivalent adult). Further, since the exchange rate in December 1998 was around 2,200 Kw, the gains are equivalent to just over 8 US dollars (at 1998 prices).

So far, we have assumed that farmers give up one hectare of own-consumption to produce an additional hectare of cotton. But the actual gains will depend on the area of cotton planted. One alternative exercise is to allow farmers to plant the average size of a typical cotton plot, which is estimated at 1.2 hectares. In this case, the constrained model generates a gain of $\mathrm{Kw} 21,878$. This is equivalent to 23.9 percent of the income of the poor. This model is perhaps more meaningful than the one-hectare exercise. It is important to notice that the average size of the land plots allocated to home production ranges from 1.5 to 5 hectares, with an unconditional average of around 2 hectares. This means that, on average, households would be able to substitute away of own-consumption activities and towards cotton growing activities.

Our findings highlight important gains from switching to cotton. However, the magnitudes do not look too high, particularly given the relevance of cotton as an export commodity. One explanation for this result is that we have been working with the constrained model, thereby a farmer must forgo income to earn cotton income. If some of these constraints were eliminated, so that households could earn extra income from cotton without giving up subsistence income, gains would be much higher. We estimate these gains with the mean cotton income, conditional on positive income and on being matched with a subsistence farmer. ${ }^{10}$ The expected gain from planting an additional hectare of cotton would be 51,516

\footnotetext{
${ }^{10}$ This matching implies two things. First, it means that the balancing property between cotton growers and subsistence farmers is satisfied. Second, it means that if a cotton farmer is too different from subsistence farmers, so that a match does not exist, then the income of this farmer is not used in the estimation of the average gain.
} 
$\mathrm{Kw}$ (or approximately 10,273 Kw per equivalent adult). These are larger gains, equivalent to around 56.4 percent of the average expenditure of poor households in rural areas. If the farmer were to grow the average size of cotton crops in Zambia (i.e., 1.2 hectares), then the gains in the unconstrained model would be $61,883 \mathrm{Kw}$, which is roughly equal to 67.7 percent of the average expenditure of the poor.

Another commercial crop with great potentials in international markets is tobacco. In the constrained model, the gain per hectare of switching from subsistence agriculture to tobacco would be 80,661 monthly kwachas, or roughly 88.2 percent of average total household expenditure. Since, on average, 0.8 hectares are allocated to tobacco, the household would gain $64,529 \mathrm{Kwachas}$ if this plot size were planted. In the unconstrained model, the gain would be $119,124 \mathrm{Kw}$, around 130 percent of the total expenditure of an average poor household. If the average of 0.8 hectares were planted (without any constrains), the income gains would reach 95,299 Kw, approximately doubling expenditure. Growing tobacco seems to be an important vehicle for poverty alleviation.

Results for vegetables and groundnuts, two activities often mentioned as good prospects for non-traditional exports, reveal that no statistically significant gains can be expected in the constrained model. In the data, there is evidence of higher earnings in planting vegetables and lower earnings in planting groundnuts but neither is statistically significant. Instead, gains can be realized if the constrains are released. For vegetables, the gain per hectare would be $89,451 \mathrm{Kw}$, or $33,991 \mathrm{Kw}$ if the average plot size devoted to this crop is planted. This is 37,2 percent of total average household expenditure. In the case of groundnuts, these gains would be equivalent to only 20 percent of the expenditure of households in poverty.

One key crop in Zambia is maize, which is grown by the vast majority of households. Farmers grow local varieties and hybrid maize. The former is mainly devoted to own-consumption and is not considered suitable for world markets. Hybrid maize is, instead, potentially exportable. In Table 8, we find that a farmer that switches from purely subsistence activities to produce (and sell) hybrid maize would make 50,933 additional kwachas. This gain, which is statistically significant, is equivalent to 55.7 percent of the expenditure of the poor. This is the expected gain, on average, since the average plot 
allocated to hybrid maize is estimated at precisely 1 hectare. If we assume that an additional hectare of maize is planted in a model without household constraints, the income differential would be 100,800 kwachas or around the average expenditure of poor households.

These are important results. To begin with, we find support for the argument that claims that income gains can be achieved through the production and sale of hybrid maize. In addition, since most Zambian farmers across the whole country grow (or grew) maize, there is a presumption that they are able to produce it efficiently and that some of the constraints faced in other crops may not be present. Know-how, fertilizer use, seeds usage, are examples. In those regions in which cotton and tobacco, major exportable crops, are not suitable agricultural activities (due to weather or soil conditions), the production of hybrid maize appears as a valid alternative.

Other crops identified as potentially exportable are cassava and sunflowers. These turn out to be irrelevant cases. The data were not good enough to allow for a meaningful evaluation of the benefits from exports. Either sample sizes were too small or the balancing conditions required to apply matching methods was not satisfied. This does not mean that there will be no gains from developing these markets but rather that the data are not suitable for our analysis. Finally, we have decided not to pursue the investigation of the cases of livestock and poultry, mainly because they involve significant initial investments. In addition, disease control is critical in these activities, and it is unclear whether Zambia will manage to achieve the standards needed to compete in international markets.

There is an additional exercise that we perform. If larger market access is achieved, rural labor markets may expand and workers may become employed and earn a wage. We can learn about the magnitudes of the income gains of moving from home plot agriculture to rural wage employment in agriculture by comparing the average income obtained in these activities. Concretely, we compare the average monthly wages of those workers employed in rural labor markets with the own-consumption per working household member in subsistence agriculture. ${ }^{11}$ In Table 8, we estimate a gain of 95,307 $\mathrm{Kw}$ per month in the constrained model (so that individuals would have to leave farming activities at home to work at a

\footnotetext{
${ }^{11}$ This is computed as the ratio of reported own-consumption and the total number of household members that work in subsistence agriculture.
} 
local large farm). In the unconstrained model (i.e., a model in which the worker becomes employed but keeps working in subsistence during the weekends), the gains would be 117,305 Kw. These gains range from 104.2 percent to 128.3 percent of the total expenditure of the average poor household in rural areas.

As in the cases of cotton, tobacco, and maize, the magnitudes of these gains suggest that rural employment in commercial farms could be good instruments for poverty alleviation. By fostering the development of larger scale agricultural activities, there is evidence that international trade opportunities can help rural farmers to move out of poverty through rural labor markets, employment and wage income.

It is important to show some evidence that the kind of switching that we are describing can actually take place. A careful answer to this question requires a panel dataset that would allow us to track farmers that switched from subsistence to market agriculture, and compare their welfare before and after the switch. Unfortunately, this type of data is not available in Zambia. However, an overview of farm dynamics can be provided by comparing the evolution of the shares of income derived from cash agriculture at different time periods. Concretely, we estimate the average share of income generated by market agriculture in 1996 and 1998 at different point of the income distribution. We use non-parametric regressions (Fan, 1992; Pagan and Ullah, 1999). Figure 2 displays the results: the solid line represents the average shares in 1998 while the broken line corresponds to the averages in 1996. The graph reveals a clear switch towards market agriculture during the 1996-98 period. Among the poorest farmers, for instance, the share of income derived from cash agriculture increased from around 2 to 8 percent to over 20 percent. From the middle to the top of the income distribution, the increase in shares is of roughly 10 percentage points.

This analysis clearly indicates that the increase in market agriculture is correlated with the observed increase in exports of non-traditional agricultural products. This implies that the expansion of these activities is not simply due to a contraction of other traditional sectors such as copper. Also, copper production is mainly an urban phenomenon affecting more urban employment than rural activities. ${ }^{12}$

\footnotetext{
${ }^{12}$ Notice, however, that there might be spillover effects through migration or remittances.
} 
Our interpretation of the results so far is as follows. We provided evidence of an increase in non-traditional exports that is concurrent with an increase in income shares coming from non-traditional agricultural. This implies that, faced with new trade opportunities, some Zambian farmers have switched from subsistence farming to cash market agriculture. This switch is only partial since many farmers continue to produce some food for own-consumption, but Figure 2 reveals that switching is indeed a possibility. In addition, we showed that there are still income gains that could potentially be realized from further switching to market agriculture. The combination of these farm dynamics with the evidence of income gains estimated in Table 8 suggests a natural role of trade and markets as vehicles for poverty alleviation.

The fact that there are income gains to be realized in market agriculture means that there are severe distortions and constraints in rural Zambia. We think of export opportunities as a way of releasing some of these constraints by providing markets for Zambian products. Access to international markets seems to be a basic prerequisite for successful poverty alleviation. But this is not enough. The realization of the gains associated with export opportunities will become feasible with complementary domestic policies. These may include extension services to farmers (transmission of information and know-how about cropping, crop diversification, fertilizer and pesticide use), the provision of infrastructure and irrigation, the development of a stronger financial and credit markets, and the provision of education (both formal education and labor discipline) and better health services.

It is easy to see why complementary policies matter. More educated households will be more prepared to face international markets, and will be more prepared to adopt new crops and production techniques. If credit is made accessible to rural farmers, a larger fraction of them will be able to cover any necessary initial investment (in seeds, fertilizer, tools) needed to substitute subsistence production for cotton production (for instance). If better infrastructure is provided, transaction and production costs will be lower, facilitating trade of cash crops. And if better marketing opportunities arise, farmers will be "closer" to the market.

It is very hard, due to data limitation, to empirically investigate the role of these 
complementary policies. ${ }^{13}$ In rural areas in Africa, though, many of the relevant issues can be illustrated by looking at extension services in agriculture. These are services provided by the government (and by some agricultural intermediaries) that give farmers information and support on a variety of topics. These include information about markets, prices, buyers, and sellers; education on technology adoption, crop diversification, and crop husbandry; information on fertilizer use, seeds, and machinery. And many other aspects of every day topics that may take place in the process of agricultural production. In consequence, we believe that a lot can be said about the role of complementary policies by looking at the impacts of extension services on farm productivity. This is only an example of the role of those policies, but one that, we believe, makes a clear point about what can be done to help farmers take full advantage of new market opportunities.

To look at extension services and farm productivity, we use data from the Zambian Post Harvest Survey. These data are collected annually by the Central Statistical Office (CSO) in Zambia. The survey is a farm survey: farmers are asked about production, yields, input use, basic household characteristics and demographics, etc. One important question for our purposes is whether the household received extension services or not. Using this information, we estimate a simple model of cotton productivity. The dependent variable is yield of cotton per hectare of cultivated land. We control for some important determinants of agricultural production, such as input use, the size of the farm, the age of the household head, year dummies and district dummies. More importantly, we include a dummy variable for whether the household received extension services of not.

Results are reported in Table 9. As expected, we find that cotton yields respond positively to the use of pesticides. The age and sex of the household head are not significant determinants of agricultural productivity. Instead, there is some evidence that smaller farmers are more productive. The last row of Table 8 reports the main result that we want to highlight: we find that households that have received extension services are on average more productive in market agriculture than households that have not received extension services. In fact, receiving agricultural extension services increases production per hectare by 8.4

\footnotetext{
${ }^{13}$ The analysis that follows was motivated by a comment from M. Slaughter to include a more detailed study of one policy.
} 
percent! This corroborates the idea that education, information, and marketing services are key factors driving the best practice supply responses that are needed to secure gains from international trade. ${ }^{14}$

\section{Expenditures}

In this section, we investigate some of the consumption effects of price reforms in Zambia. We begin by describing the structure of expenditure. Table 10 reports the average budget shares spent by Zambian households in different goods in 1998. As expected, most of the budget was spent on food, with a national average share of 67.5 percent. The average was higher in rural areas (reaching 73.6 percent) and lower in urban areas (56.6 percent). Further, the poor spent a larger share of total expenditure on food than the non-poor. At the national level, for instance, 71.7 percent of the total expenditure of an average poor family was devoted to food, while for non-poor households the average was 59.2 percent.

Other goods accounting for a significant share of total expenditure were Personal Items, Housing, Transport, Alcohol \& Tobacco and Education. However, these average shares were always below 10 percent. The usual differences between urban and rural households, and between the poor and the non-poor were observed. For instance, non-poor households tended to spend a larger fraction of expenditure on Clothing, Personal Items, Housing and Transportation. Budget shares on Education and Health were not different across poor and non-poor households. Comparing rural and urban households, we find that rural households consumed more food, and urban households more Personal Items, Housing, Transportation and Education. Shares spent on Clothing, Health, and Alcohol \& Tobacco were not very different.

There is one fundamental lesson that can be learnt from Table 10. In Zambia, as in many low income developing countries, the largest fraction of household expenditure is spent on food. In consequence, the largest impacts of trade policies and economic reforms on the consumption side will be caused by changes in the prices of food items. Expenditures on

\footnotetext{
${ }^{14}$ For a more detailed analysis of cotton reforms and farm productivity, see Brambilla and Porto (2004).
} 
other non-food items are relatively less important in terms of total expenditure, the welfare impacts being lower as a result.

Maize is the main food item consumed in Zambia. There are four main types of maize consumption: home produced maize, mugaiwa, roller maize and breakfast meal. Roller and breakfast meal comprise industrial maize produced by large scale mills. Both are finely grinded maize, but roller is a lower quality staple. Mugaiwa is the meal composed of maize grain that is grinded by small scale hammermills. Sometimes farmers (especially women) take the peel off the grain before taking it to the hammermill, leading to a tastier maize meal.

Table 11 shows that maize consumption indeed accounts for a large share of expenditure. In $1998,18.5$ percent of the average budget went to maize outlays at the national level; the corresponding figures in rural and urban areas were 21 percent and 14.2 percent. The total expenditure on maize was relatively balanced between home production, industrial maize and mugaiwa. However, it is clear that households in rural areas spent a larger share on home produced maize and on mugaiwa than households in urban areas, which spent more on industrial maize. There were important provincial differences in maize shares. In Lusaka, which includes the capital city, the average household devoted a moderate share to maize, mostly to industrial varieties. In Luapula and in Northern province, the shares spent on maize were much lower. This is because these regions specialize in growing cassava rather than maize (and, in Luapala, fishing is a key economic activity). In the remaining provinces, maize was the main staple.

Zambia adopted large reforms in the maize sector during the 1990s. Before 1993, maize marketing was controlled by a maize marketing board, which set prices for maize grain and maize meal. In particular, breakfast and roller meals were heavily subsidized. In 1993, the government eliminated all price controls. Given the importance of maize as a food expenditure in Zambia, in what follows we investigate the consumption effects of the elimination of these large consumption subsidies.

The government subsidized maize to consumers by regulating maize milling and sales. Large-scale mills located in urban centers distributed industrial maize (breakfast and roller 
meal) throughout the country and controlled most of the market for maize meal. Small-scale mills (hammermills) were not allowed to participate in maize marketing. Their function was to mill own-produced grain for home consumption. Because of the subsidies to production and industrial maize, it was often cheaper for rural consumers to sell their harvested maize and buy cheap milled maize.

When the marketing board was eliminated, consumer prices for breakfast and roller maize increased significantly. However, the government liberalized the small-scale hammermill sector, allowing mills to enter the market. This facilitated the growth of consumption of mugaiwa, a cheaper form of maize meal where households would bring grain to the small hammermills for grinding services. The introduction of competition in the milling industry allowed for the availability of cheaper varieties of meal maize and consumers were able to ameliorate the negative impacts of the elimination of the subsidies.

There is a caveat, though. In times of production shortages, Zambia resorts to imported maize to satisfy food needs. Traditionally, industrial large-scale mills, as opposed to hammermills, have been able to import maize or have been granted preferential access to publicly imported grain (Mwiinga et al., 2002). These constraints on small-scale mills can force households to consume larger shares of industrial maize, and lower shares of mugaiwa meal, with consequent welfare costs in terms of food security.

We turn next to the investigation of the consumption effects of the reforms. ${ }^{15}$ When the marketing board was eliminated, industrial maize became too expensive for many households. ${ }^{16}$ On top of the higher cost due to the removal of the subsidy, the privatized mill industry could have acted as a monopoly, leading to prices well above marginal costs. With large average budget shares spent on industrial maize (Table 10), such price increases would have significant welfare costs for Zambian consumers. For instance, a 100 percent increase in prices with a budget share of 15 percent among poor households in urban areas would

\footnotetext{
${ }^{15}$ Due to lack of data on input use and transport costs at the household level, we do not investigate the welfare losses caused by the elimination of support prices to producers, which is therefore left as a topic for future research.

${ }^{16}$ Anecdotal evidence indicates that, in 1991, when the Zambian government first attempted to get rid of the marketing board as recommended by the IMF, prices of industrial maize in urban areas raised by as much as 100 percent. This led to riots and demonstrations that forced the government to reverse the initial reform.
} 
lead to a welfare loss of 15 percent of initial total household expenditure.

To assess the impacts of these reforms on consumers, we would like to estimate a system of demand for different varieties of maize and use the structural parameters of demand to carry out an evaluation of the policy changes. In the case of Zambia, data constraints make it impossible to carry out a comprehensive examination of the dynamics of maize demand. It is possible, however, to provide a simpler analysis of the costs of the removal of the subsidies by looking at budget shares. As shown by Deaton (1989), the effect of a price change can be approximated by budget shares.

For our purposes, there are three relevant budget shares: on maize own-consumption, on breakfast and roller maize (industrial maize), and on mugaiwa maize. We are interested in capturing the extent of substitution responses in the consumption of different types of maize. We can do this by estimating the average budget share, conditional on the level of household expenditure. To estimate these averages non-parametrically, we use Fan (1992) locally weighted regressions. We estimate a regression function for 1991 (before the maize reforms) and another for 1998 (after the reform).

Figure 3 plots the non-parametric averages by level of per equivalent adult expenditure for rural Zambia in 1991. In the Priority Survey, we only have information on the share spent on industrial maize. Expenditure on mugaiwa was negligible, since the milling industry was not liberalized, and the expenditure on own-consumption was not disaggregated into individual components. In any case, it is possible to observe that the share of industrial maize expenditure declines with income (as predicted by Engel Law). For the poorest households, the shares reach 14 percent of the budget. These large fractions are explained in part by the prevalence of the consumer subsidies.

Figure 4 estimates the Fan regressions after the reforms. The Living Conditions Monitoring Survey for 1998 includes data on many types of maize consumption. Thus, we can describe the whole pattern of household expenditures. The solid line represents the average budget share spent on industrial maize (breakfast and roller), the broken line, the share spent on own consumption, and the dotted line, on mugaiwa. We observe that the most important source of maize meal in 1998 is mugaiwa, particularly for poorer households 
(which show shares of over 15 percent of total expenditure). The share of own-consumption increases with income at the bottom of the distribution, and then declines with it as income grows. Instead, the share of industrial maize is relatively constant at all income levels.

This analysis clearly shows how rural households have substituted away from industrial maize and towards mugaiwa maize. Estimates by Mwiinga et al. (2002) indicate that the price of mugaiwa maize (which involves grain expenses plus milling services) is only about 60 to 80 percent of the price of industrial maize. The pattern of substitution reported by Zambian households thus reveals the benefits brought about by the possibility of having access to this cheaper source of maize meal. For this to be possible, liberalization of the market was critical. Moreover, it is even possible for consumers to benefit from the overall reforms (elimination of marketing board and concurrent liberalization of mills) if, due to the deregulation, mugaiwa prices declined (much) below the price of industrial maize before the reform. ${ }^{17}$

As already mentioned, there are some restrictions on small mills imposed by the government. Since Zambia substantially relies on maize for food security, the country must resort to imports in times of production shortages. Typically, the government would grant special privileges to import maize to large scale mills. They were allowed to import maize, or they were given preferential access to government-imported maize. This implies that local maize shortages, as those observed in 2001/2002 would be accompanied by a shortage of mugaiwa. As a result, consumers would be forced to purchase more expensive industrial maize. The estimated averages give us a sense of the important welfare effects that this type of regulations can impose on poor rural households.

\section{Conclusions}

In this paper, we have investigated some of the impacts of international trade and economic reforms on rural households in Zambia. This is a low income country, with widespread and prevalent poverty at the national and regional levels. In rural areas, poverty is still higher.

\footnotetext{
${ }^{17}$ Unfortunately, there is no data on mugaiwa prices before the reform to better assess this outcome.
} 
In this context, efforts devoted to find ways to alleviate poverty should be welcome. In Zambia, the government and international institutions have long been actively searching for programs and policies to improve the living standards of the population. Concretely, a set of reforms were implemented during the 1990s, including liberalization, privatization, and deregulation of marketing boards in agriculture. Further, farmers and firms were encouraged to look more closely at international markets.

After episodes of economic reforms, households are affected both as consumers and as income earners. Consequently, we have looked at these two aspects of the globalization-poverty link. On the income side, we have estimated income gains from market agriculture vis-a-vis subsistence agriculture. On the consumption side, we have investigated the effects of the elimination of the consumer subsidies on maize that were caused by the elimination of the maize marketing board.

International trade and export growth would bring about an increase in the demand for traded goods produced by Zambian farmers. This includes cotton, tobacco, hybrid maize, vegetables, and groundnuts. Further, by raising the demand for rural labor, rural wages would increase as well. Our results indicate that rural Zambians would gain substantially from expanding world markets, particularly in terms of cotton, tobacco, and maize income as well as of wages.

For this to be feasible, Zambia needs to have access to international markets. On the one hand, this requires the liberalization of world agricultural markets. But complementary policies would also be essential. On the production side, these include extension services (information), infrastructure (transport), irrigation, access to credit and finance, education, and health services.

The elimination of consumer subsidies on the main staple, maize, caused large welfare losses on rural households. Here, complementary policies were shown to have important effects as well. On the one hand, the liberalization of the milling industry allowed for the surge and development of the consumption of mugaiwa maize. This is a cheaper source of maize meal. This allowed for a strong substitution pattern in consumption whereby households would consume less of the expensive industrial maize varieties and more of the 
cheaper mugaiwa. On the other hand, the restrictions on imports of maize by small mills limited the extent of substitution that was feasible in times of maize production shortages.

\section{References}

Barnum, H. and L. Squire (1979). "A model of an Agricultural Household. Theory and Evidence," World Bank Ocassional Papers No 27.

Benjamin, D. (1992). "Household Composition, Labor Markets, and Labor Demand: Testing for Separation in Agricultural Household Models," Econometrica 60, 287-322.

Brambilla, I. and G. Porto (2004). "Farm Productivity and Crop Choice. Evidence From Cotton Marketing Reforms in Zambia," mimeo Yale University.

Cotton News (2002). Cotton Development Trust, Zambia.

Deaton, A. (1989). "Rice Prices and Income Distribution in Thailand: a Non-Parametric Analysis," Economic Journal, vol. 99, pp. 1-37.

Deaton, A. (1990). "Price Elasticities from Survey Data," Journal of Econometrics, vol. 44, pp. 281-309.

Deaton, A. (1997). The Analysis of Household Surveys. A Microeconometric Approach to Development Policy, John Hopkins University Press for the World Bank.

Dehejia, R., and S. Wahba (2002). "Propensity Score Matching Methods for Non-Experimental Causal Studies," Review of Economic Studies, vol. 84, No 1, pp. 151-161.

Fan, J. (1992). "Design-adaptive Nonparametric Regression," Journal of the American Statistical Association, vol. 87, No 420, December, pp. 998-1004.

Food Security Research Project (2000). "Improving Smallholder and Agribusiness Opportunities in Zambia's Cotton Sector: Key Challenges and Options," Working Paper No 1, Lusaka, Zambia.

Heckman, J., H. Ichimura, J. Smith, and P. Todd (1996). "Sources of Selection Bias in Evaluating Social Programs: An Interpretation of Conventional Measures and Evidence on the Effectiveness of Matching as a Program Evaluation Method," Proceedings of the National Academy of Sciences, vol. 93 (23), pp. 13426-13420.

Heckman, J., H. Ichimura, and P. Todd (1997). "Matching as an Econometric Evaluation Estimator: Evidence from Evaluating a Job Training Programme," Review of Economic Studies, vol. 64 (4), pp. 605-654.

Heckman, J., H. Ichimura, and P. Todd (1998). "Matching as an Econometric Evaluation Estimator," Review of Economic Studies, vol. 65 (2), pp. 261-294. 
Lalonde, R. (1986). "Evaluating the Econometric Evaluations of Training Programs," American Economic Review, 76(4), pp. 604-620.

Litchfield, J. and N. McCulloch (2003). "Poverty in Zambia: Assessing the Impacts of Trade Liberalization in the 1990s," mimeo, Poverty Research Unit, Sussex University.

McCulloch, N., B. Baulch, and M. Cherel-Robson (2001). "Poverty, Inequality and Growth in Zambia During the 1990s," presented at WIDER Development Conference, Helsinski, May 2001.

Mwiinga, W., J. Nijhoff, T. Jayne, G. Tembo and J. Shaffer (2002). "The Role of Mugaiwa in Promoting Household Food Security," Policy Synthesis No 5, Food Security Research Project, Zambia.

Pagan, A. and A. Ullah (1999). Nonparametric Econometrics. Cambridge University Press, New York.

Porto, G. (2004). "Informal Export Barriers and Poverty," forthcoming Journal of International Economics.

Rosenbaum, P., and D. Rubin (1983). "The Central Role of the Propensity Score in Observational Studies of Causal Effects," Biometrika, 70(1), pp. 41-55.

Rubin, D. (1977). "Assignment to a Treatment Group on the Basis of a Covariate," Journal of Educational Statistics, 2(1) pp. 1-26.

Singh, I., L. Squire, and J. Strauss, eds. (1986). Agricultural Household Models: Extensions, Applications and Policy, Baltimore, Johns Hopkins University Press for the World Bank.

Winters, A., N. McCulloch, and A. McKay (2004). "Trade Liberalization and Poverty: The Evidence So Far," Journal of Economic Literature, XLII, pp. 72-115.

World Bank (1994). Zambia Poverty Assessment, Washington DC. 
Table 1

Poverty in Zambia

(head count)

\begin{tabular}{lccc}
\hline \hline & 1991 & 1996 & 1998 \\
\hline National & 69.6 & 80.0 & 71.5 \\
Rural & 88.3 & 90.5 & 82.1 \\
Urban & 47.2 & 62.1 & 53.4 \\
\hline \hline
\end{tabular}

Note: The head count is the percentage of the population below the poverty line. Own calculations based on Priority Survey (1991), Living Conditions Monitoring Survey (1996) and Living Conditions Monitoring Survey (1998).

Table 2

Poverty Profile in 1998 (head count)

\begin{tabular}{lccc}
\hline \hline & total & rural & urban \\
\hline National & 71.5 & 82.1 & 53.4 \\
Central & 74.9 & 82.3 & 60.5 \\
Copperbelt & 63.2 & 82.1 & 57.5 \\
Eastern & 79.1 & 80.6 & 64.4 \\
Luapula & 80.1 & 84.6 & 52.4 \\
Lusaka & 48.4 & 75.7 & 42.4 \\
Northern & 80.6 & 83.3 & 66.4 \\
North-Western & 74.3 & 77.4 & 54.1 \\
Southern & 68.2 & 73.0 & 51.8 \\
Western & 88.1 & 90.3 & 69.5 \\
\hline \hline
\end{tabular}

Note: The head count is the percentage of the population below the poverty line. Own calculations based on the Living Conditions Monitoring Survey (1998). 
Table 3

Major Economic Reforms. Zambia 1989-1998

\begin{tabular}{|c|c|c|c|c|}
\hline Year & $\begin{array}{l}\text { Stabilization Policy } \\
\text { and Key Events }\end{array}$ & $\begin{array}{l}\text { Agricultural Price } \\
\text { and Marketing }\end{array}$ & Trade Reforms & $\begin{array}{l}\text { Parastatal Reform } \\
\text { and Privatization }\end{array}$ \\
\hline 1989 & $\begin{array}{l}\text { Decontrol of all con- } \\
\text { sumer prices (except } \\
\text { maize). }\end{array}$ & $\begin{array}{l}\text { Abolition of national } \\
\text { maize marketing } \\
\text { board. }\end{array}$ & & \\
\hline 1990 & $\begin{array}{l}\text { Policy Framework Pa- } \\
\text { per agreed with IMF. }\end{array}$ & $\begin{array}{l}\text { Demonopolization of } \\
\text { agricultural marketing; } \\
\text { maize meal subsidy } \\
\text { withdrawn. }\end{array}$ & & \\
\hline 1991 & $\begin{array}{l}\text { IMF suspends dis- } \\
\text { bursements in June. } \\
\text { Inflation soars. Elec- } \\
\text { tion of MMD in } \\
\text { October. }\end{array}$ & & $\begin{array}{l}\text { Removal of most ex- } \\
\text { port controls; removal } \\
\text { of ban on maize ex- } \\
\text { ports. }\end{array}$ & \\
\hline 1992 & $\begin{array}{l}\text { Introduction of Treas- } \\
\text { ury Bill Financing; de- } \\
\text { control of borrowing } \\
\text { and lending rates; in- } \\
\text { troduction of "bureau } \\
\text { de change" for ex- } \\
\text { change rate determina- } \\
\text { tion. }\end{array}$ & $\begin{array}{l}\text { Severe drought; re- } \\
\text { moval of mealie meal } \\
\text { subsidy; removal of fer- } \\
\text { tilizer subsidy. }\end{array}$ & $\begin{array}{l}\text { Simplification and } \\
\text { compression of tariff } \\
\text { rates; increase in the } \\
\text { tariff preference for } \\
\text { goods from COMESA. }\end{array}$ & \\
\hline 1993 & $\begin{array}{l}\text { Introduction of cash } \\
\text { budgeting. }\end{array}$ & $\begin{array}{l}\text { Failed attempt to re- } \\
\text { form agricultural mar- } \\
\text { keting. }\end{array}$ & & $\begin{array}{l}\text { Privatization act } \\
\text { passed; Zambia Privat- } \\
\text { ization Agency formed }\end{array}$ \\
\hline 1994 & $\begin{array}{l}\text { Capital account liber- } \\
\text { alization. }\end{array}$ & $\begin{array}{l}\text { Launch of the Agricul- } \\
\text { tural Credit Manage- } \\
\text { ment Programme. }\end{array}$ & & \\
\hline 1995 & & $\begin{array}{l}\text { Privatization of the } \\
\text { milling industry; } \\
\text { launch of WB agricul- } \\
\text { tural sector investment } \\
\text { programme. }\end{array}$ & $\begin{array}{l}\text { Removal of } 20 \text { percent } \\
\text { uplift factor applied to } \\
\text { import values. }\end{array}$ & $\begin{array}{l}\text { Dissolution of the Zam- } \\
\text { bia Industria and Min- } \\
\text { ning Corportation (ZI- } \\
\text { MCO). }\end{array}$ \\
\hline 1996 & $\begin{array}{l}\text { MMD wil elections } \\
\text { but UNIP boycott } \\
\text { elections. }\end{array}$ & & & $\begin{array}{l}\text { Acceleration of privat- } \\
\text { ization programme. }\end{array}$ \\
\hline 1997 & $\begin{array}{l}\text { Donors withdraw bal- } \\
\text { ance of payment sup- } \\
\text { port. }\end{array}$ & & & \\
\hline 1998 & $\begin{array}{l}\text { Copper prices ad- } \\
\text { versely affected by } \\
\text { East Asian crisis. }\end{array}$ & & & $\begin{array}{l}\text { Negotiations on Zam- } \\
\text { bia Consolidated Cop- } \\
\text { per Mines (ZCCM) sale } \\
\text { fall through. }\end{array}$ \\
\hline
\end{tabular}

Source: McCullogh, Baulch and Cherel-Robson (2001) and Litchfield and McCullogh (2003). 
Table 4

Exports, 1990-1999

(millions of US dollars)

\begin{tabular}{|c|c|c|c|c|c|c|c|c|}
\hline & \multirow[b]{2}{*}{1990} & \multirow[b]{2}{*}{1995} & \multirow[b]{2}{*}{1996} & \multirow[b]{2}{*}{1997} & \multirow[b]{2}{*}{1998} & \multirow[b]{2}{*}{1999} & \multicolumn{2}{|c|}{ Annual Growth Rate } \\
\hline & & & & & & & $\begin{array}{c}\text { Actual } \\
1990-1999\end{array}$ & $\begin{array}{l}\text { Projected } \\
1999-2010\end{array}$ \\
\hline Metal Exports & 1168 & 1039 & 754 & 809 & 630 & 468 & & \\
\hline Non-Traditional Exports & 89 & 178 & 226 & 315 & 308 & 298 & & \\
\hline Primary Agriculture & 15 & 24 & 38 & 91 & 62 & 73 & $22 \%$ & $13 \%$ \\
\hline Floricultural Products & 1 & 14 & 18 & 21 & 33 & 43 & $52 \%$ & $13 \%$ \\
\hline Textiles & 9 & 39 & 40 & 51 & 42 & 37 & $17 \%$ & $13 \%$ \\
\hline Processed \& Refined Foods & 6 & 25 & 34 & 31 & 49 & 33 & $24 \%$ & $17 \%$ \\
\hline Horticultural Products & 5 & 4 & 9 & 16 & 21 & 24 & $19 \%$ & $13 \%$ \\
\hline Engineering Products & 20 & 39 & 37 & 42 & 32 & 23 & $2 \%$ & $8 \%$ \\
\hline Semi-Precious Stones & 8 & 8 & 11 & 15 & 12 & 14 & $21 \%$ & $13 \%$ \\
\hline Building Materials & 4 & 5 & 8 & 12 & 9 & 10 & $11 \%$ & $8 \%$ \\
\hline Other Manufactures & 0 & 1 & 1 & 3 & 3 & 7 & & $11 \%$ \\
\hline Petroleoum Oils & 11 & 11 & 6 & 2 & 7 & 6 & $-7 \%$ & $7 \%$ \\
\hline Chemical Products & 3 & 2 & 3 & 8 & 7 & 6 & $8 \%$ & $-4 \%$ \\
\hline Animal Products & 2 & 1 & 2 & 3 & 4 & 4 & $8 \%$ & $16 \%$ \\
\hline Wood Products & 1 & 1 & 2 & 3 & 3 & 3 & $13 \%$ & $8 \%$ \\
\hline Leather Products & 1 & 2 & 2 & 2 & 3 & 2 & $8 \%$ & $16 \%$ \\
\hline Non-Metallic Minerals & 2 & 1 & 1 & 1 & 1 & 1 & & $13 \%$ \\
\hline Garments & 3 & 0 & 0 & 0 & 0 & 0 & $-20 \%$ & $23 \%$ \\
\hline Handicrafts & 0 & 0 & 0 & 0 & 0 & 0 & $29 \%$ & $11 \%$ \\
\hline Re-exports & 0 & & 4 & 4 & 4 & 3 & & \\
\hline Scrap Metal & 0 & & 11 & 6 & 4 & 6 & & $0 \%$ \\
\hline Mining & 0 & & & 4 & 12 & 3 & & \\
\hline Total Commodity Exports & 1257 & 1217 & 981 & 1123 & 937 & 766 & $-5 \%$ & $11 \%$ \\
\hline Metal Share of Total & $93 \%$ & $85 \%$ & $77 \%$ & $72 \%$ & $67 \%$ & $61 \%$ & & \\
\hline
\end{tabular}

Source: Bank of Zambia and IMF. 
Table 5

Sources of Income

(percentage)

\begin{tabular}{|c|c|c|c|c|c|c|c|c|c|}
\hline & \multicolumn{3}{|c|}{ National } & \multicolumn{3}{|c|}{ Rural } & \multicolumn{3}{|c|}{ Urban } \\
\hline & total & poor & non-poor & total & poor & non-poor & total & poor & non-poor \\
\hline Own Production & 28.3 & 33.3 & 19.1 & 42.5 & 42.9 & 42.0 & 3.3 & 4.4 & 2.4 \\
\hline Sales of Food Crops & 6.3 & 7.6 & 3.8 & 9.1 & 9.5 & 7.6 & 1.4 & 1.7 & 1.1 \\
\hline Sales on non-Food Crops & 2.5 & 3.0 & 1.3 & 3.8 & 4.0 & 2.9 & 0.1 & 0.1 & 0.1 \\
\hline Livestock \& Poultry & 5.5 & 6.8 & 2.9 & 8.1 & 8.7 & 5.9 & 0.8 & 1.0 & 0.7 \\
\hline Wages & 20.8 & 14.4 & 32.9 & 6.9 & 5.9 & 10.3 & 45.3 & 40.3 & 49.4 \\
\hline Income non-farm & 22.3 & 20.9 & 24.9 & 16.8 & 16.3 & 18.3 & 32.0 & 34.7 & 29.7 \\
\hline Remittances & 4.9 & 5.0 & 4.8 & 5.3 & 5.0 & 6.1 & 4.3 & 4.9 & 3.9 \\
\hline \multirow[t]{2}{*}{ Other sources } & 9.5 & 9.0 & 10.3 & 7.5 & 7.7 & 6.9 & 12.8 & 13.0 & 12.7 \\
\hline & 100.0 & 100.0 & 100.0 & 100.0 & 100.0 & 100.0 & 100.0 & 100.0 & 100.0 \\
\hline
\end{tabular}

Note: The table reports income shares. Own calculations based on Living Conditions Monitoring Survey (1998). 
Table 6

Income Shares, Average Income and Sample Sizes

\begin{tabular}{|c|c|c|c|c|c|c|c|c|c|c|}
\hline Province & 1 & 2 & 3 & 4 & 5 & 6 & 7 & 8 & 9 & Total \\
\hline \multicolumn{11}{|l|}{ Cotton } \\
\hline -share of inc & 8.4 & 0 & 9.5 & 0 & 0.8 & 0 & 0.1 & 2.8 & 0.2 & 3.1 \\
\hline -mean of inc & 50688 & 12808 & 24791 & . & 58447 & 167 & 10134 & 37016 & 12827 & 32254 \\
\hline -sample size & 177 & 1 & 370 & 0 & 24 & 1 & 9 & 91 & 11 & 684 \\
\hline \multicolumn{11}{|l|}{ Vegetables } \\
\hline -share of inc & 1.1 & 2.8 & 0.3 & 0.2 & 1.2 & 0.7 & 0.5 & 1.7 & 0.3 & 0.8 \\
\hline -mean of inc & 18774 & 7560 & 3291 & 3951 & 42630 & 3811 & 2071 & 4468 & 10872 & 7108 \\
\hline -sample size & 68 & 87 & 46 & 27 & 53 & 100 & 92 & 151 & 18 & 642 \\
\hline \multicolumn{11}{|l|}{ Tobacco } \\
\hline -share of inc & 0.2 & 0.1 & 2.3 & 0 & 0 & 0 & 0.1 & 0.2 & 0.1 & 0.5 \\
\hline -mean of inc & 41472 & 2434 & 58529 & 715 & 833 & 1001 & 2348 & 103252 & 38609 & 40590 \\
\hline -sample size & 10 & 11 & 67 & 8 & 1 & 8 & 21 & 8 & 5 & 139 \\
\hline \multicolumn{11}{|l|}{ Groundnuts } \\
\hline -share of inc & 0.9 & 0.7 & 2.4 & 2 & 0.2 & 1.4 & 1.1 & 0.4 & 0.2 & 1.2 \\
\hline -mean of inc & 6101 & 8605 & 4024 & 8510 & 16268 & 3941 & 7343 & 5746 & 2733 & 5316 \\
\hline -sample size & 107 & 53 & 290 & 184 & 22 & 259 & 97 & 92 & 31 & 1135 \\
\hline \multicolumn{11}{|l|}{ Paprika } \\
\hline -share of inc & 0 & 0 & 0.1 & 0 & 0 & 0 & 0 & 0 & 0 & 0 \\
\hline -mean of inc & 30579 & 1609 & 14116 & . & . & 250 & . & . & . & 13767 \\
\hline -sample size & 4 & 2 & 4 & 0 & 0 & 1 & 0 & 0 & 0 & 11 \\
\hline \multicolumn{11}{|l|}{ Industrial maize } \\
\hline -share of inc & 6.1 & 2 & 0.7 & 0.3 & 1.7 & 0.6 & 0.3 & 1.4 & 0.5 & 1.3 \\
\hline -mean of inc & 60377 & 24162 & 21075 & 20160 & 37910 & 9617 & 14924 & 36458 & 8929 & 33897 \\
\hline -sample size & 152 & 68 & 56 & 18 & 73 & 53 & 33 & 114 & 34 & 601 \\
\hline \multicolumn{11}{|l|}{ Cassava } \\
\hline -share of inc & 0.3 & 0.2 & 0.1 & 4.1 & 0 & 2.4 & 2.2 & 0.1 & 1.3 & 1.2 \\
\hline -mean of inc & 4148 & 1970 & 30753 & 7532 & 7910 & 4084 & 5162 & 12060 & 3760 & 5438 \\
\hline -sample size & 43 & 18 & 9 & 242 & 3 & 331 & 214 & 13 & 71 & 944 \\
\hline \multicolumn{11}{|l|}{ Maize } \\
\hline -share of inc & 4.4 & 3.1 & 3.2 & 0.5 & 1.1 & 0.9 & 3.8 & 0.9 & 2.6 & 2.2 \\
\hline -mean of inc & 13603 & 14825 & 10069 & 4575 & 14210 & 5758 & 7179 & 9463 & 7013 & 9209 \\
\hline -sample size & 122 & 114 & 186 & 56 & 49 & 108 & 332 & 103 & 142 & 1212 \\
\hline \multicolumn{11}{|l|}{ Rice } \\
\hline -share of inc & 0 & 0 & 0.3 & 0.1 & 0 & 0.1 & 0 & 0 & 1.2 & 0.2 \\
\hline -mean of inc & . & 1250 & 4614 & 6664 & . & 3884 & 1502 & . & 8040 & 5762 \\
\hline -sample size & 0 & 1 & 39 & 9 & 0 & 31 & 3 & 0 & 48 & 131 \\
\hline
\end{tabular}

(cont.) 
Table 6 (cont.)

Income Shares, Average Income and Sample Sizes

\begin{tabular}{|c|c|c|c|c|c|c|c|c|c|c|}
\hline Province & 1 & 2 & 3 & 4 & 5 & 6 & 7 & 8 & 9 & Total \\
\hline \multicolumn{11}{|l|}{ Millet } \\
\hline -share of inc & 0.9 & 0.1 & 0.2 & 0.3 & 0 & 1.3 & 0 & 0 & 0.2 & 0.4 \\
\hline -mean of inc & 4821 & 1402 & 4253 & 2338 & & 2727 & 1574 & 2250 & 3161 & 2965 \\
\hline -sample size & 26 & 12 & 29 & 48 & 0 & 222 & 7 & 1 & 33 & 378 \\
\hline \multicolumn{11}{|l|}{ Sorghum } \\
\hline -share of inc & 0.1 & 0.2 & 0 & 0 & 0.1 & 0.2 & 0.5 & 0 & 0.2 & 0.1 \\
\hline -mean of inc & 3409 & 5220 & 838 & 1209 & 35209 & 1938 & 4473 & 0 & 3002 & 3166 \\
\hline -sample size & 17 & 17 & 4 & 12 & 5 & 45 & 60 & 1 & 16 & 177 \\
\hline \multicolumn{11}{|l|}{ Beans } \\
\hline -share of inc & 0.2 & 0.1 & 0 & 0.5 & 0 & 2 & 0.8 & 0 & 0 & 0.5 \\
\hline -mean of inc & 6486 & 1922 & 6388 & 9668 & 8631 & 11007 & 3679 & 2679 & 2412 & 8598 \\
\hline -sample size & 18 & 17 & 12 & 49 & 2 & 219 & 95 & 8 & 3 & 423 \\
\hline \multicolumn{11}{|l|}{ Soya beans } \\
\hline -share of inc & 0.4 & 0 & 0.4 & 0.1 & 0 & 0 & 0 & 0 & 0 & 0.1 \\
\hline -mean of inc & 26102 & 3611 & 6277 & 6250 & 5427 & 3958 & 868 & 652 & & 10989 \\
\hline -sample size & 19 & 3 & 30 & 1 & 2 & 6 & 2 & 2 & 0 & 65 \\
\hline \multicolumn{11}{|l|}{ Sweet potatoe } \\
\hline -share of inc & 0.9 & 2.8 & 0.1 & 1 & 0 & 0.3 & 1.6 & 0.1 & 0.5 & 0.7 \\
\hline -mean of inc & 5827 & 5547 & 2800 & 1820 & 1746 & 2082 & 3841 & 2546 & 5292 & 3658 \\
\hline -sample size & 57 & 154 & 26 & 110 & 9 & 124 & 159 & 29 & 29 & 697 \\
\hline \multicolumn{11}{|l|}{ Irish potatoe } \\
\hline -share of inc & 0 & 0.1 & 0 & 0.1 & 0 & 0 & 0.3 & 0.1 & 0 & 0.1 \\
\hline -mean of inc & 9987 & 8935 & 2494 & 5810 & 333333 & 2443 & 4321 & 25420 & & 8135 \\
\hline -sample size & 5 & 6 & 7 & 6 & 1 & 6 & 31 & 13 & 0 & 75 \\
\hline \multicolumn{11}{|l|}{ Sunflower } \\
\hline -share of inc & 0.1 & 0 & 0.5 & 0 & 0 & 0.1 & 0.1 & 0.2 & 0 & 0.1 \\
\hline -mean of inc & 12656 & 4167 & 4834 & 750 & 7738 & 3424 & 1100 & 5770 & & 5472 \\
\hline -sample size & 17 & 1 & 38 & 1 & 4 & 13 & 5 & 45 & 0 & 124 \\
\hline \multicolumn{11}{|l|}{ Livestock } \\
\hline -share of inc & 2.9 & 1.3 & 4.3 & 0.6 & 3.8 & 2 & 2.3 & 8 & 6.9 & 3.8 \\
\hline -mean of inc & 16126 & 11606 & 11910 & 11808 & 14285 & 8701 & 12955 & 44612 & 14936 & 19442 \\
\hline -sample size & 165 & 63 & 342 & 51 & 149 & 215 & 133 & 409 & 177 & 1704 \\
\hline \multicolumn{11}{|l|}{ Poultry } \\
\hline -share of inc & 6.4 & 2.2 & 4.5 & 2.7 & 5.9 & 3.4 & 2.8 & 4.6 & 6.7 & 4.3 \\
\hline -mean of inc & 3329 & 6530 & 2550 & 2061 & 5967 & 1940 & 2220 & 3762 & 1501 & 2778 \\
\hline -sample size & 476 & 228 & 766 & 476 & 291 & 731 & 510 & 637 & 365 & 4480 \\
\hline
\end{tabular}

Note: Income shares are in percentage and mean of income in monthly Kwachas. Own calculations based on Living Conditions Monitoring Survey (1998). 
Table 7

Probit Estimates

Selection into Market Agriculture

\begin{tabular}{|c|c|c|c|c|c|c|}
\hline & Cotton & Tobacco & Groundnuts & Vegetables & Maize & Wages \\
\hline constant & $\begin{array}{l}-1.338 \\
(0.796)\end{array}$ & $\begin{array}{l}-4.233 \\
(1.821)\end{array}$ & $\begin{array}{l}-2.210 \\
(0.709)\end{array}$ & $\begin{array}{l}-0.331 \\
(0.734)\end{array}$ & $\begin{array}{l}-0.777 \\
(0.988)\end{array}$ & $\begin{array}{c}2.264 \\
(0.919)\end{array}$ \\
\hline \multirow[t]{2}{*}{ married } & -0.135 & 0.892 & 0.289 & -0.466 & -0.250 & 0.470 \\
\hline & $(0.254)$ & $(0.614)$ & $(0.187)$ & $(0.200)$ & $(0.177)$ & $(0.154)$ \\
\hline \multirow[t]{2}{*}{ male } & 0.357 & 0.506 & -0.364 & 0.365 & 0.275 & -1.241 \\
\hline & $(0.242)$ & $(0.485)$ & $(0.188)$ & $(0.223)$ & $(0.193)$ & $(0.152)$ \\
\hline \multirow[t]{2}{*}{ age } & 0.009 & 0.094 & -0.016 & -0.031 & 0.005 & -0.100 \\
\hline & $(0.027)$ & $(0.070)$ & $(0.019)$ & $(0.024)$ & $(0.021)$ & $(0.049)$ \\
\hline \multirow[t]{2}{*}{ age sq. } & 0.000 & -0.001 & 0.000 & 0.000 & 0.000 & 0.001 \\
\hline & $(0.000)$ & $(0.001)$ & $(0.000)$ & $(0.000)$ & $(0.000)$ & $(0.001)$ \\
\hline \multirow[t]{2}{*}{ primary } & 0.448 & -0.012 & 0.055 & 0.158 & 0.164 & 0.054 \\
\hline & $(0.154)$ & $(0.306)$ & $(0.122)$ & $(0.150)$ & $(0.114)$ & $(0.160)$ \\
\hline \multirow[t]{2}{*}{ high school (jr.) } & 0.390 & 0.134 & 0.295 & 0.427 & 0.277 & 0.375 \\
\hline & $(0.203)$ & $(0.676)$ & $(0.149)$ & $(0.168)$ & $(0.133)$ & $(0.170)$ \\
\hline \multirow{2}{*}{ high school (sr.) } & 0.255 & -0.591 & -0.418 & 0.523 & 0.405 & 0.964 \\
\hline & $(0.361)$ & $(0.877)$ & $(0.387)$ & $(0.279)$ & $(0.226)$ & $(0.254)$ \\
\hline \multirow[t]{2}{*}{ higher education } & 0.774 & 0.000 & -0.318 & 1.006 & 1.450 & 1.127 \\
\hline & $(0.889)$ & $(0.000)$ & $(0.687)$ & $(0.431)$ & $(0.449)$ & $(0.407)$ \\
\hline \multirow[t]{2}{*}{ hh males } & -0.183 & 0.884 & 0.309 & -0.005 & -0.058 & 0.986 \\
\hline & $(0.342)$ & $(0.769)$ & $(0.246)$ & $(0.293)$ & $(0.237)$ & $(0.323)$ \\
\hline \multirow[t]{2}{*}{ hh age $8-12$} & -0.151 & -0.495 & 0.469 & -0.462 & 0.692 & 0.626 \\
\hline & $(0.529)$ & $(1.248)$ & $(0.419)$ & $(0.515)$ & $(0.401)$ & $(0.498)$ \\
\hline \multirow[t]{2}{*}{ hh age $13-18$} & -0.121 & 0.070 & 0.082 & -0.047 & 0.156 & 0.668 \\
\hline & $(0.461)$ & $(0.960)$ & $(0.347)$ & $(0.399)$ & $(0.347)$ & $(0.446)$ \\
\hline \multirow[t]{2}{*}{ hh age $19-45$} & 0.092 & -1.594 & 0.351 & -0.550 & 0.399 & 1.259 \\
\hline & $(0.399)$ & $(1.011)$ & $(0.322)$ & $(0.398)$ & $(0.304)$ & $(0.368)$ \\
\hline \multirow[t]{2}{*}{ hh age $46+$} & -0.025 & -0.425 & 0.532 & -0.449 & -0.044 & 2.610 \\
\hline & $(0.466)$ & $(1.025)$ & $(0.336)$ & $(0.434)$ & $(0.362)$ & $(0.544)$ \\
\hline \multirow[t]{2}{*}{ hh ill } & -0.814 & 0.271 & -0.526 & -0.075 & 0.060 & -0.402 \\
\hline & $(0.340)$ & $(0.552)$ & $(0.236)$ & $(0.293)$ & $(0.238)$ & $(0.302)$ \\
\hline \multirow[t]{2}{*}{ dist. food market } & 0.007 & 0.013 & -0.003 & -0.003 & 0.004 & -0.014 \\
\hline & $(0.004)$ & $(0.007)$ & $(0.002)$ & $(0.003)$ & $(0.002)$ & $(0.004)$ \\
\hline \multirow[t]{2}{*}{ dist. mill } & 0.012 & & 0.000 & -0.007 & 0.000 & -0.038 \\
\hline & $(0.006)$ & & $(0.003)$ & $(0.005)$ & $(0.003)$ & $(0.015)$ \\
\hline \multirow[t]{2}{*}{ dist. inputs } & -0.003 & 0.005 & -0.001 & 0.000 & -0.005 & 0.000 \\
\hline & $(0.003)$ & $(0.007)$ & $(0.002)$ & $(0.002)$ & $(0.002)$ & $(0.002)$ \\
\hline \multirow[t]{2}{*}{ dist. water } & & 0.096 & -0.104 & -0.168 & -0.149 & \\
\hline & & $(0.261)$ & $(0.088)$ & $(0.113)$ & $(0.082)$ & \\
\hline \multirow[t]{2}{*}{ tools } & 0.603 & -0.618 & -0.069 & 0.375 & 0.411 & \\
\hline & $(0.147)$ & $(0.441)$ & $(0.177)$ & $(0.169)$ & $(0.124)$ & \\
\hline \multirow[t]{2}{*}{ owner } & -0.121 & -1.142 & 0.056 & -0.104 & -0.418 & -1.555 \\
\hline & $(0.400)$ & $(0.586)$ & $(0.292)$ & $(0.273)$ & $(0.226)$ & $(0.177)$ \\
\hline \multirow[t]{2}{*}{ land } & 0.030 & 0.362 & 0.077 & 0.014 & 0.142 & 0.058 \\
\hline & $(0.024)$ & $(0.094)$ & $(0.024)$ & $(0.026)$ & $(0.016)$ & $(0.018)$ \\
\hline Number of obs & 914 & 294 & 2138 & 1746 & 2053 & 2280 \\
\hline Treated & 141 & 37 & 159 & 118 & 265 & 139 \\
\hline Non-treated & 773 & 257 & 1979 & 1628 & 1788 & 2141 \\
\hline Pseudo $R^{2}$ & 0.21 & 0.31 & 0.17 & 0.26 & 0.34 & 0.50 \\
\hline
\end{tabular}

Note: Probit estimates of the probability of producing cash crops. Regressions also include district dummies not shown in the table. Standard errors in parenthesis. Married, male, age, age squared and education dummies (attend, primary, high school jr., high school sr., and higher education) refer to household head. hh males is the share of males in the household. hh age 8-12, hh age 13-18, hh age 19-45, hh age $46+$, are the shares of household members between ages 8 and 12,13 and 18,19 and 45, and over 46, respectively. hh ill is the share of ill members in the household. dist. food market, dist. mill, dist. inputs, and dist. water are distances (in Km.) to the nearest food market, mill, crop inputs market, and water, respectively. Owner is a dummy that equals 1 if the household owns its farm. 
Table 8

Income Gains in Market Agriculture

\begin{tabular}{|c|c|c|c|c|c|c|c|c|}
\hline & \multicolumn{2}{|c|}{$\begin{array}{l}\text { Constrained Model } \\
\text { (per ha) }\end{array}$} & \multicolumn{2}{|c|}{ Constrained Model } & \multicolumn{2}{|c|}{$\begin{array}{l}\text { Unconstrained Model } \\
\text { (per ha) }\end{array}$} & \multicolumn{2}{|c|}{ Unconstrained Model } \\
\hline & Total & $\begin{array}{c}\% \text { of } \\
\text { expenditure }\end{array}$ & Total & $\begin{array}{c}\% \text { of } \\
\text { expenditure }\end{array}$ & Total & $\begin{array}{c}\% \text { of } \\
\text { expenditure }\end{array}$ & Total & $\begin{array}{c}\% \text { of } \\
\text { expenditure }\end{array}$ \\
\hline Cotton & $\begin{array}{l}18232 \\
(7456)\end{array}$ & 19.9 & $\begin{array}{l}21878 \\
(8947)\end{array}$ & 23.9 & $\begin{array}{l}51569 \\
(6731)\end{array}$ & 56.4 & $\begin{array}{l}61883 \\
(8077)\end{array}$ & 67.7 \\
\hline Tobacco & $\begin{array}{c}80661 \\
(26336)\end{array}$ & 88.2 & $\begin{array}{c}64529 \\
(21069)\end{array}$ & 70.6 & $\begin{array}{l}119124 \\
(28402)\end{array}$ & 130.3 & $\begin{array}{c}95299 \\
(22722)\end{array}$ & 104.2 \\
\hline Groundnuts & $\begin{array}{r}-11717 \\
(9120)\end{array}$ & -12.8 & $\begin{array}{l}-4452 \\
(3466)\end{array}$ & -0.05 & $\begin{array}{l}49165 \\
(5606)\end{array}$ & 53.8 & $\begin{array}{l}18683 \\
(2130)\end{array}$ & 20.4 \\
\hline Vegetables & $\begin{array}{c}40852 \\
(25381)\end{array}$ & 44.7 & $\begin{array}{l}15524 \\
(9645)\end{array}$ & 17.0 & $\begin{array}{l}89451 \\
(25257)\end{array}$ & 97.8 & $\begin{array}{l}33991 \\
(9597)\end{array}$ & 37.2 \\
\hline Maize & $\begin{array}{c}50933 \\
(11341)\end{array}$ & 55.7 & $\begin{array}{c}50933 \\
(11341)\end{array}$ & 55.7 & $\begin{array}{l}100800 \\
(9989)\end{array}$ & 110.2 & $\begin{array}{c}100800 \\
(9989)\end{array}$ & 110.2 \\
\hline Cassava & $* *$ & & $* *$ & & $* *$ & & $* *$ & \\
\hline Sunflower & $* *$ & & $* *$ & & $* *$ & & $* *$ & \\
\hline Wages & & & $\begin{array}{c}95307 \\
(10525)\end{array}$ & 104.2 & & & $\begin{array}{l}117305 \\
(10089)\end{array}$ & 128.3 \\
\hline
\end{tabular}

Note: Results from propensity score matching of market agriculture farmers and subsistence farmers using kernel methods. Standard errors in parenthesis are estimated with bootstrap methods. The Constrained Model (per ha) assumes that the household has to give up one hectare of land to produce an additional hectare of a given cash crop (such as cotton). The Constrained Model assumes that the farmer moves from subsistence to market agriculture and allocates the average plot size of each cash crop (e.g., 1.2 hectares in the case of cotton). The Unconstrained Models assume that the farmer can allocate additional land to the cash crops without giving up subsistence production. 
Table 9

Extension Services and Market Agricultural Productivity

\begin{tabular}{lcc}
\hline \hline $\begin{array}{l}\text { Yield per } \\
\text { hectare }\end{array}$ & Coef. & Std. Err. \\
\hline Constant & 5.761 & 0.238 \\
Head male & 0.077 & 0.052 \\
Head age & $-2.67 \mathrm{E}-04$ & 0.008 \\
Head age (sq) & $-3.33 \mathrm{E}-06$ & $8.05 \mathrm{E}-05$ \\
Small & 0.159 & 0.046 \\
Pesticide & 2.250 & 0.725 \\
Pesticide (sq) & -3.160 & 1.810 \\
Extension & & \\
Services & 0.084 & 0.040 \\
\hline
\end{tabular}

Obs.: 2187

$\mathrm{R}^{2}: 0.17$

Note: Own calculations based on Post Harvest Surveys. The regression includes year and district dummies.

Table 10

Average Budget Shares

(percentage)

\begin{tabular}{|c|c|c|c|c|c|c|c|c|c|}
\hline & \multicolumn{3}{|c|}{ National } & \multicolumn{3}{|c|}{ Rural } & \multicolumn{3}{|c|}{ Urban } \\
\hline & total & poor & non-poor & total & poor & non-poor & total & poor & non-poor \\
\hline Food & 67.5 & 71.8 & 59.3 & 73.6 & 74.6 & 70.3 & 56.6 & 63.1 & 51.2 \\
\hline Clothing & 5.6 & 4.8 & 7.1 & 5.6 & 5.2 & 7.0 & 5.5 & 3.6 & 7.1 \\
\hline Alcohol \& Tobacco & 3.6 & 2.9 & 4.9 & 3.7 & 3.0 & 6.0 & 3.3 & 2.3 & 4.1 \\
\hline Personal Goods & 7.1 & 6.8 & 7.6 & 5.7 & 6.1 & 4.5 & 9.5 & 9.1 & 9.9 \\
\hline Housing & 4.5 & 4.2 & 5.0 & 2.9 & 3.0 & 2.4 & 7.3 & 7.7 & 6.9 \\
\hline Education & 2.5 & 2.6 & 2.3 & 1.9 & 2.1 & 1.0 & 3.6 & 3.9 & 3.3 \\
\hline Health & 1.4 & 1.3 & 1.6 & 1.3 & 1.3 & 1.5 & 1.7 & 1.5 & 1.7 \\
\hline Transport & 4.2 & 3.2 & 5.9 & 3.4 & 3.1 & 4.3 & 5.5 & 3.6 & 7.1 \\
\hline Remittances & 1.3 & 0.7 & 2.4 & 1.0 & 0.7 & 1.9 & 1.9 & 0.8 & 2.8 \\
\hline \multirow[t]{2}{*}{ Other } & 2.4 & 1.7 & 3.9 & 0.9 & 0.8 & 1.2 & 5.1 & 4.2 & 5.9 \\
\hline & 100.0 & 100.0 & 100.0 & 100.0 & 100.0 & 100.0 & 100.0 & 100.0 & 100.0 \\
\hline
\end{tabular}

Note: The table reports budget shares. Own calculations based on Living Conditions Monitoring Survey (1998). 
Table 11

Maize Consumption

(percentage)

\begin{tabular}{lrrrrrrrrrr}
\hline \hline Province & 1 & 2 & 3 & 4 & 5 & 6 & 7 & 8 & 9 & Total \\
\hline Total Maize & 22.5 & 17.6 & 29.3 & 3.7 & 14 & 5.6 & 14.9 & 25.2 & 32.9 & 18.5 \\
Rural & 26.3 & 22.9 & 30.5 & 2.9 & 25.1 & 4.7 & 14.6 & 28.6 & 33.4 & 21 \\
Urban & 16.1 & 15.7 & 17.7 & 9.7 & 11.9 & 10.8 & 17.2 & 12.9 & 27.7 & 14.2 \\
Home Production & 7.6 & 1.6 & 14.7 & 1.1 & 0.9 & 2 & 6.8 & 5.2 & 12 & 5.4 \\
$\quad$ Rural & 11.6 & 4.8 & 16 & 1.2 & 5.2 & 2.1 & 7.5 & 6.5 & 13 & 8.2 \\
Urban & 0.9 & 0.4 & 2.5 & 0.6 & 0.1 & 0.9 & 2.2 & 0.5 & 2 & 0.5 \\
Industrial & 5.2 & 12.9 & 3.4 & 1 & 10.7 & 1.2 & 2.7 & 6.7 & 7.4 & 6.5 \\
Rural & 2.4 & 9.3 & 3.2 & 0.4 & 7.7 & 0.7 & 2.2 & 6.4 & 6.9 & 3.8 \\
Urban & 10 & 14.1 & 4.8 & 5.1 & 11.3 & 4.4 & 6.5 & 8 & 12.6 & 11.1 \\
Mugaiwa & 9.6 & 3.1 & 11.2 & 1.6 & 2.4 & 2.4 & 5.3 & 13.3 & 13.6 & 6.6 \\
$\quad$ Rural & 12.3 & 8.7 & 11.2 & 1.3 & 12.1 & 1.9 & 4.9 & 15.8 & 13.6 & 9 \\
Urban & 5.1 & 1.1 & 10.5 & 3.9 & 0.5 & 5.5 & 8.5 & 4.4 & 13.2 & 2.5 \\
\hline \hline
\end{tabular}

Note: The table reports budget shares (over total expenditure). Provinces are indexed as follows. 1: Central, 2: Copperbelt, 3: Eastern, 4: Luapala, 5: Lusaka, 6: Northern, 7: North-Western, 8: Southern, 9: Western. Own calculations based on Living Conditions Monitoring Survey (1998). 
Figure 1

Propensity Score in Cotton

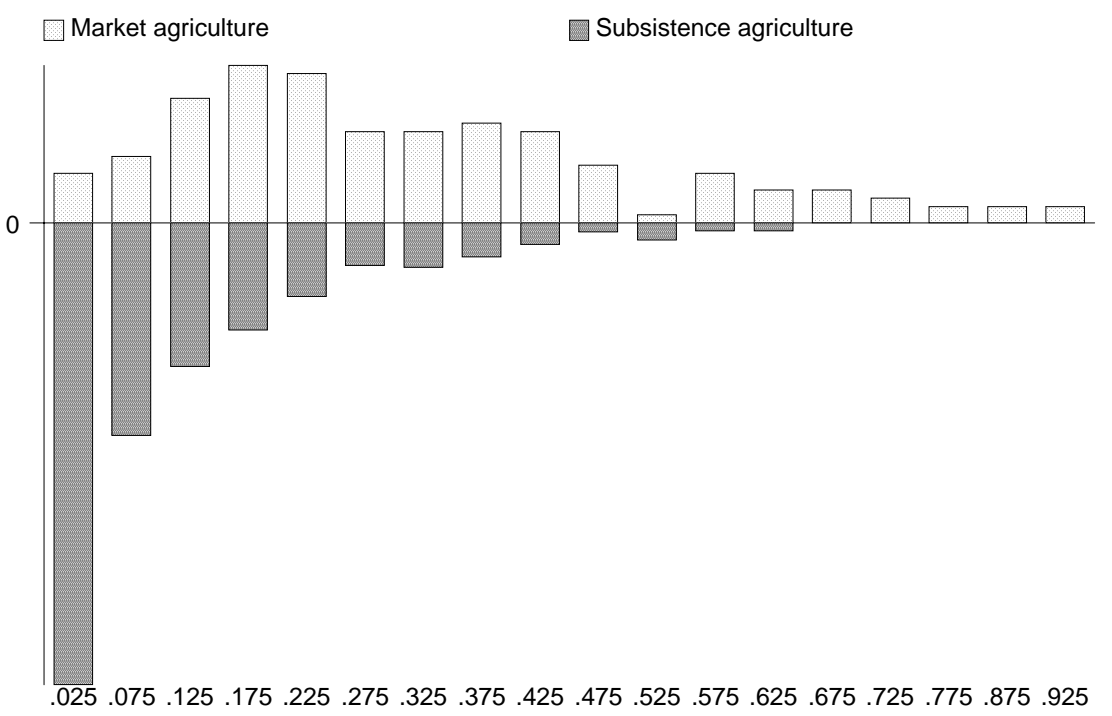

Note: The graph shows the proportion of market agriculture households and subsistence agriculture households for different values of the propensity score. 
Figure 2

Income Shares Derived From Cash Agriculture

$1991-1998$

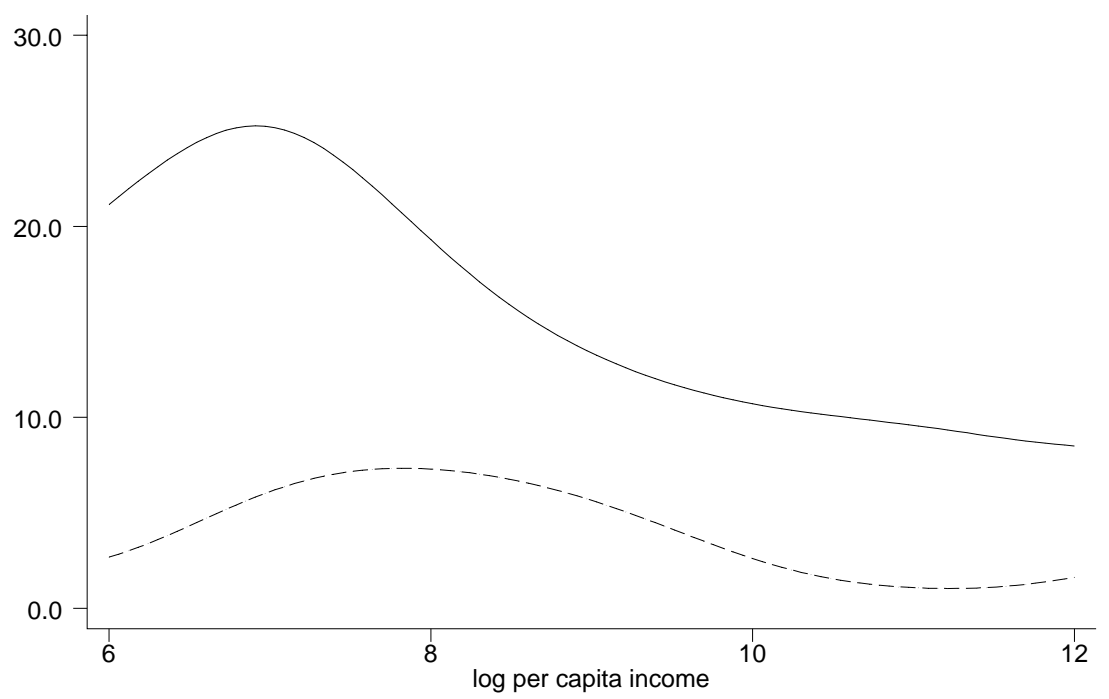

Note: The graph shows the average shares of income derived from cash market agriculture. The solid and dotted lines represent the share estimated with 1998 and 1996 data respectively. The averages are estimated with non-parametric locally weighted regressions (Fan, 1992). 
Figure 3

Share of Maize Meals in Rural Zambia

Before Reforms (1991)

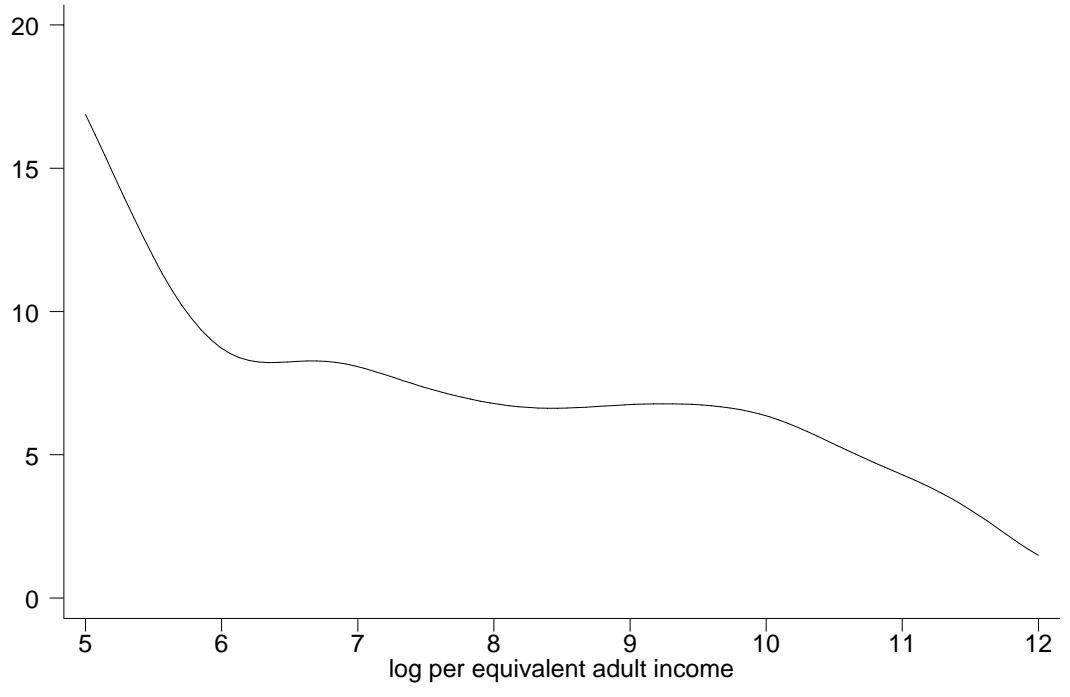

Note: The graph shows the average budget share spent on industrial maize in rural areas. The averages are estimated with non-parametric locally weighted regressions (Fan, 1992).

Figure 4

Share of Maize Meals in Rural Zambia

After Reforms (1998)

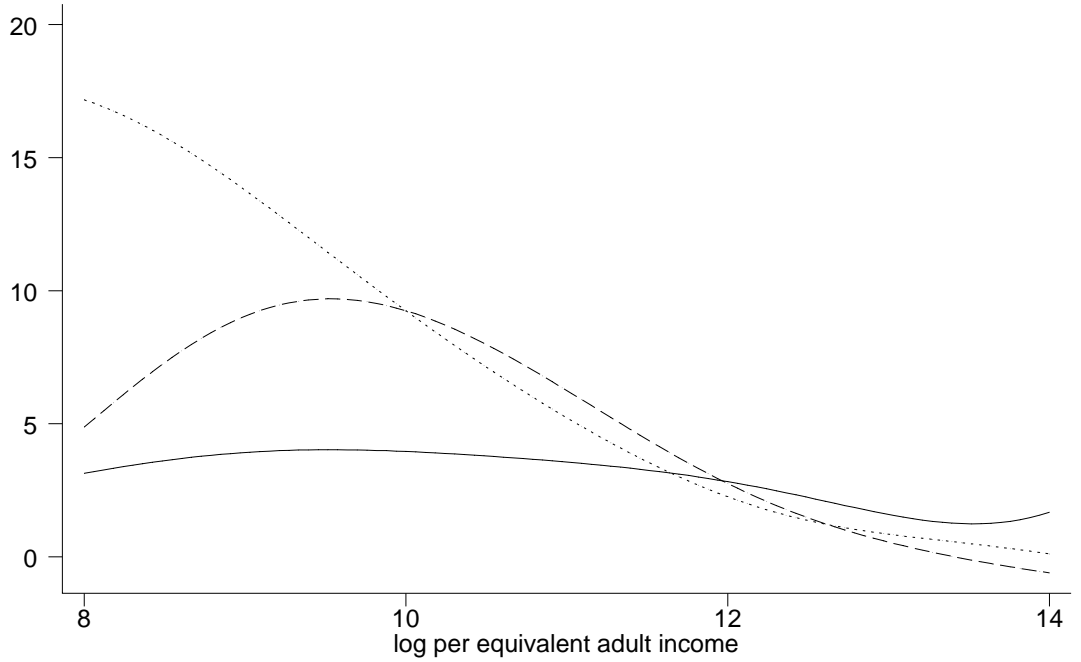

Note: The graph shows the average budget shares spent on maize. The solid line represents the share of industrial maize, the broken line, the share of own consumption, and the dotted line, the share spent on mugaiwa. The averages are estimated with non-parametric locally weighted regressions (Fan, 1992). 